\title{
THE TRADITIONS OF PLURALISM, ACCOMMODATION, AND ANTI-RADICALISM IN THE PESANTREN COMMUNITY'
}

\author{
Ronald Lukens-Bull \\ The University of North Florida, USA
}

\begin{abstract}
Western media and Western policy makers sometimes perceive traditional Islamic schools throughout the Islamic world as a source of radicalism. The history of pesantren in Indonesia shows that this is not only mistaken but also a perspective that leads the West away from a potential ally in the efforts to create a world of peaceful coexistence. The mystical traditions of pesantren form a strong basis from which most Indonesians have eschewed radical Islamism. These traditions are rooted in the popular Muslim folklore surrounding the foundation of Islam in Indonesia. This paper argues that more recent history shows the foundations of current debates regarding the establishment of shariath as the law of the land as well as some actions of the Suharto regime inadvertently encouraged the growth of radical Islamism. Finally, the paper concludes that, in order to fully understand the current situation and the future, more research is needed. A few starting points are discussed in this paper.
\end{abstract}

Keywords: Walisongo, pesantren, gamelan, wayang.

\section{Introduction}

Contrary to the perceptions of Western media and Western policymakers, traditional Islamic schools in Indonesia are not a source of radicalism but a source of anti-radicalism and an ally in the efforts to establish peace and harmony in the world. Pesantren (Islamic

\footnotetext{
1 This paper was originally presented at the "Muslim Youth as Agents of Change Conference", Malang, Indonesia, 27-29 November 2007, sponsored by Leiden University and the Indonesian Ministry of Religious Affairs.
} 
boarding schools $)^{2}$ leaders frequently speak about how the classical tradition brought by the Wali Songo (Nine Saints or Nine Friends of God) and continued in pesantren through the study of classical texts called kitab kuning inoculates students from more radical forms of Islam. In a very real sense, the best answer to radical Islam is not liberal Islam but conservative classical Islam.

This paper takes on four related tasks. The first will be to outline the development of the pesantren tradition as a tradition of accommodation. The second will be to examine the place of mysticism in the pesantren community. The third will be to explore the emergence of radical Islamist groups in the context of the New Order and the efforts to establish a democratic society after its collapse. Finally because the end of the New Order has meant changes in Indonesia generally and in the pesantren community more specifically, the last section will explore possible new direction for research on these current trends.

\section{A Tradition of Accommodation}

Islam first came to Indonesia when Islam and Sufism were indivisible; to be a Muslim was to be a mystic or a sufi. ${ }^{3}$ Indonesia more than any other Islamic country has maintained this aspect of classical Islam. And within Indonesia, the pesantren community is responsible for continuing the teachings and practices of classical Islam. In general, mystical traditions in all religions focus more on personal piety over social order. Mystics are often more concerned about how individuals live their lives and how they seek God than they are about having a society that enforces religious ideals. A focus on personal piety leads to a great acceptance of variation within a given tradition. Such internal tolerance naturally breeds tolerance towards those outside the tradition.

The development of pesantren in Indonesia cannot be disassociated from the development of sufi orders. From the beginning, pesantren have served itself as the center of the teaching of sufi subjects and the kyais have been, and are, the persistent

\footnotetext{
2 There are 3 English terms that all are close in capture the sense of the meaning of pesantren, but all fall to fully convey the full meaning: Islamic boarding school, Islamic seminary, Islamic monastery.

3 Anthony Johns, "Tariqah," in Mircea Eliade (editor in chief), The Encyclopaedia of Religion (New York: Macmillan Publishing Company, 1987), pp. 342-352.
} 
disseminators of sufi orders mainly through teaching and learning processes in the pesantren. The term 'pesantren' itself is derived from Sanskrit which means the place for cantrik, whose literal meaning is 'disciple' in spiritual sense. This indicates that the establishment and institutionalization of pesantren in Indonesia has a close relationship with local culture and it approaches the society by customizing itself into the deep structure of society's culture. What makes pesantren is acceptable and accessible to society is the fact that its mode of development coincides with the widespread existing spiritual values of the society by means of acculturation and assimilation process.

\section{Wali Songo as Founders of Pesantren Tradition}

The pesantren world in Java is nearly as old as Islam in Java itself. Both in print, and in oral tradition, pesantrens are closely tied to the Wali Songo (the nine saints who brought Islam to Java). The first, if not the most famous, of the Wali Songo, Sunan Maulana Malik Ibrahim is said to have established the first pesantren in Java in 1399 CE (Common Era) in order to train muballigh (preachers) to further spread Islam in Java. ${ }^{4}$

Other accounts aver that all the Wali Songo had pesantren, which is supported by a few published sources. ${ }^{5}$ Despite that none of the Wali Songo pesantren have survived to present day, all pesantrens are their intellectual descendents and all kyais are seen as inheritors of the role of the Wali Songo which is frequently mentioned in pesantren circles. There are few leaders who do claim to be descendants of one of the Wali Songo. Those men and those who affiliate themselves with them are drawing specific connections between themselves and the archetypes of kyai, the Wali Songo. ${ }^{6}$

Several of the Wali Songo are known for making accommodations with local culture. Specifically, they are known for their use of wayang (shadow puppet theatre). One way this was done was by reinterpreting the Hindu epics. For example, in the Mahabarata, Arjuna has a secret weapon called the Kalimasada, which some Javanese Muslims say is short for Kalimah Shahada, or the Islamic Confession of Faith. Some

\footnotetext{
4 Abdul Ghofir, et al., Sketsa Pondok Pesantren: Laporan Hasil Studi and Eksperimentasi Pondok Pesantren di Jawa Timur (Malang: Fakultas Tarbiyah IAIN Sunan Ampel, 1982).

${ }^{5}$ Mahmud Yunus, Sejarah Pendidikan Islam di Indonesia (Jakarta: Mutiara, 1979), p. 217.

${ }^{6}$ Ronald Lukens-Bull, A Peaceful Jihad: Negotiating Identity and Modernity in Muslim Java (New York: Palgrave McMillian, 2005), pp. 1-6.
} 
have argued that the highly stylized human forms in the Javanese wayang puppets reflect the influence of Islam which discourages the artistic representation of the human form. The Wali Songo are also known for incorporating the gamelan (percussion orchestra), the slit gong, and the beduk (large drum) into the call for prayer. The purported logic was that by using sounds that people already associate with large gatherings, people would be more interested in attending the prayers.

Another key Wali Songo is Sunan Kudus, who is said to have originated the wayang golek, the three-dimensional wooden puppet show and for building the Kudus mosque. The cultural accommodation of the Wali Songo is further celebrated in a story that describes how because the residents of Kudus were predominately Hindu. Sunan Kudus built his mosque to resemble a Hindu temple and forbade his followers from eating beef. To this day, the Kudus area, now predominately Muslim, is known for the fact that the inhabitants do not eat beef but favor water buffalo.

The Wali Songo, Kalijaga in particular, taught Islam through local art and culture, specifically the slametan (ritual meal) and the wayang or shadow puppet theater. ${ }^{7}$ To this day there are pesantrens that sponsor wayang, gamelan orchestras, and other cultural events. ${ }^{8}$ Pesantren Lirboyo, perhaps one of the most famous traditional pesantrens, hosts an annual exhibition of Javanese martial arts (pencak silat) which draws crowds in the thousands.

The Wali Songo legends are crucial for understanding the development of Indonesian Islam. Because kyais are considered to have inherited the role of these saints, most kyais adopt the style and methods of the Wali Songo. This means meeting people where they are. Rather than preaching against popular practices like slametan and ziarah (pilgrimage to holy tombs), they accept that people want to do these things and strive to teach them a more orthodox way of conducting and understanding these rituals. This history also means that Indonesian Islam has a strong pietistic element, meaning that doing right is left to the individual's conscience. The pace of preachers

\footnotetext{
7 Mark R. Woodward, Islam in Java: Normative Piety and Mysticism in the Sultanate of Yogyakarta (Tucson: The University of Arizona Press, 1989), p. 96.

8 Bambang Pranowo, "Traditional Islam in Contemporary Rural Java," in M.C. Ricklefs (ed.), Islam in the Indonesian Social Context (Clayton: Monash University Center for Southeast Asian Studies Lecture Series, 1991).
} 
and teachers is to heighten awareness (keyakinan) so that people will be inspired to live a good Muslims. Frequently repeated is the Qur'anic injunction that there should "be no compulsion in religion" (Q.S. 2:256). Therefore the establishment of shari $x_{h}$ as a national law enforced by the state has long been rejected by most Indonesian Muslims.

\section{Mysticism in Pesantren}

Mysticism as found in traditional pesantren follows the sober mysticism of al-Ghazaland hence balances the mystical dimensions of the faith with the normative practices. Furthermore, mysticism is seen as a critical component in pesantren education not only does it provide the basis for a moral compass but because it provides a sense of balance and direction in an often confusing modern world.

Gus Ishom9 of Tebu Ireng said that tas hownuf (A: mysticism, Sufism) is central in moral education. He expounded that in Islam there is a "triangle" of major "sciences" (ilmu): tawhi (A: theology; especially as regards the nature of Allah), fiqh (A: religious law), and tasdwwnf. Each of these sciences makes different contributions. Tawbi establishes the basis of faith because faith is not enough and needs "good works" ("amal) to actualize it. Figh provides the believers with guidelines on how to live right and perform good works. Since good works, alone, are empty if the motivation is impure, tas hownuf is needed to instill moral and ethical values in believers. The association of Sufism and ethics in the Indonesian pesantren may be traced to a single highly influential Islamic thinker, namely al-Ghaza $\gg$ Al-Ghaza\$ $>$ is famous for his sober mysticism, which balanced theology and tasawwuf and his extensive works on ethics. The use and study of alGhaza works that are abundant in the pesantren world associate mysticism and ethics. In history and legend as well, mysticism came to Indonesia through the Wali Songo, the nine saints who responsible for bringing Islam to the archipelago.

The Wali Songo have great mystical feats attributed to them. Sunan Kalijaga is said to have mediated without ceasing for 40 years. Another of the Wali Songo is said to have been able to fly to Mecca for Friday prayers and be back home in Java for his afternoon repast.

\footnotetext{
9 Ishom is a descendent of Hasyim Asyari, who is arguably the most famous of the Indonesian kyai.
} 
Some contemporary kyais also have great power associated with them. Some are able to heal -mostly psychological and spiritual maladies such as homesickness, mental illness (sakit jiwa), drug abuse, and spirit (jin) possession. Others are known for esoteric knowledge- being able to look at people and know what problems bring them before the kyai and know the best way to solve these problems. Abdurrahman Wahid, the fourth President of Indonesia, was said to have predicted his oven election long before he was a candidate. Others are said to be able to still waves with their meditations (tapas). Other can walk through rain without getting wet and even be in tow places at once. What is important here is the perceived power of mystical believes and practices.

\section{Mysticism as Source of Tolerance}

An important episode out of the Wali Songo legends is the story of Syaikh Siti Jenar. Syaikh Siti Jinar was one of the nine but he taught the unorthodox notion that since God is one, there was no separation between himself and God and that he was therefore God. He was summarily executed; not for being incorrect in his assertion, but for teaching something that would confuse the common believer. While at first glance, this seems to be a story of intolerance; it is not. This tale emphasized the importance of balancing the normative and mystical dimensions of Islam. This means contrary to the opinions of salafi Muslims and other modernists who are known for destroying graves, the classical Islam found in pesantren allows room for the mystical practices of both the adept and the commoner as long they do not interfere with the basic articles of faith.

Although not universally true, there is strong tendency for mystical traditions to enhance tolerance. First and foremost, mystical traditions allow the logical possibility of more than one may to be faithful. In the Indonesian context, mystical practice acknowledges and allows a wide range of practices including saint's grave pilgrimage (ziarah), ritual meals (slametan), and the use of amulets. On the other hand, modernists have discouraged many of these practices even to the extent of destroying graveyards. While it may be true that common people (wong cilik) may become confused (from an orthodox point of view) and pray to the saints, or propitiate spirits during a slametan, various kyais have repeatedly told me that it is critical to embrace these practices. Only by embracing the practices of the common person, can religious leaders bring them into a fuller and more correct understan- 
ding. Greater tolerance within a religion opens the logical possibility of greater tolerance between religions.

A clear lesson from the Wali Songo legends is Indonesia's long history on emphasizing personal piety and personal responsibility. Debates within the Islamic community regarding the relationship with the government began shortly after the establishment of the Republic of Indonesia, when there was a great debate about whether or not Muslims could accept a secular government.

\section{Jakarta Charter and Shari ah Law}

The first draft of the Preamble of 1945 Constitution, known as the Jakarta Charter (Piagam Jakarta), required all Muslim to follow Islamic law (shari $\gg$ h). ${ }^{10}$ The "seven words" that granted such a requirement were deleted by the panel of nine writers, eight of whom were Muslims, including Wahid Hasyim of Tebu Ireng. ${ }^{11}$ This action established the Republic of Indonesia as a secular state. ${ }^{12}$ This was contrary to the hopes of many ulama for the creation of an Indonesian Islamic State (Negara Islam Indonesia) when the Republic was born. ${ }^{13}$

Periodically, the specter of the Jakarta Charter raises its head and gives rise to much debate. However, even the leadership of the Islamist-leaning Dewan Dakwah acknowledges that the issue of an Islamic state is over and that pluralism will remain the basis of Indonesian society. Further, they argued that even if shari ath law could

10 Deliar Noer, Administration of Islam in Indonesia (Ithaca: Cornell Modern Indonesia Project, 1978), p. 12.

${ }^{11}$ Tebu Ireng is arguably the most famous of pesantren. Wahid Hasyim is the son of Hadratus Syaikh Hasyim Asyari, one of the most famous of early 20th century Kyai and a co-founder of Nahdlatul Ulama. Both Wahid and his father, Hasyim are seen a saints are the graveyard in Tebu Ireng, where they both are buried attracts up to 2000 pilgrims each month. Abdurrahman Wahid, the fourth president of Indonesia, is the son of Wahid Hasyim and grandson of Hasyim Asyari. See, Zamakhsyari Dhofier, The Pesantren Tradition: A Study of the Role of the Kyai in the Maintenance of the Traditional Ideology of Islam in Java (Canberra, Doctoral Thesis submitted to The Australian National University, 1980), p. 163.

12 Taufik Abdullah, "The Pesantren in Historical Perspective," in Taufik Abdullah and Sharon Siddique (eds.), Islam and Society in Southeast Asia (Singapore: Institute of Southeast Asian Studies, 1987), p.65.

13 B.J. Boland, The Struggle of Islam in Modern Indonesia (The Hague: Nijhoff, 1971), pp. 15-34. 
be put into practice, the rights of the minorities have to be defended. Further they stated, "Islamic Law is for Muslims, but not for nonMuslims. Muslims who do not want to fast or pray is another problem that must be addressed". ${ }^{14}$ However, they made it perfectly clear that people cannot be forced to do these things. In fact, the surath that states that there must be no compulsion in religion is widely cited. Instead, Muslims have to be convinced to carry out 'ibath through da`wah and teaching.

The ongoing effort to establish shari axh law not only in Indonesia but throughout the Islamic world is a defining characteristic of Islamism, including the specific subset of Islamism often referred to as radicalism or radical Islamism. In the context of Indonesian Islam, radical Islamism is one of the factors that challenges the tradition of tolerance and pluralism.

\section{Historical Jihad}

The concept of holy war was invoked a number of times in the history of Indonesian Islam. There were numerous rebellions which used Islamic symbols to motivate and mobilize the masses including the Cilegon Affair, ${ }^{15}$ the Java War led by Prince Diponegoro, ${ }^{16}$ and the War for Independence. Many nineteenth century rebellions were led by kyais. Kyais and their santri were very much involved in Indonesia's struggle for independence. In the written and oral histories of many pesantren is an accounting of the role played by its personnel during the war. For example, Hasyim Asy'ari of Tebu Ireng is said to have rejuvenated the independence effort by declaring that the war against the Dutch was jihad and required (wajib) for every Muslim within an eighty kilometer radius of the enemy. Other kyais lead their santri as guerrilla cells. This nearly universal claim of having some role in the war effort is a claim of identity; namely, that the pesantren community fought hard to be Indonesian. Less talked about was the involvement of pesantren people in the 1965-66 communist purges. Muslim groups were recruited by the military to find and kill alleged communists.

\footnotetext{
${ }^{14}$ Interview, 2000.

15 Sartono Kartodirdjo, The Peasants' Revolt of Banten in 1888 (The Hague: Martinus Nijhoff, 1966).

16 Michael Adas, Prophets of Rebellion: Millenarian Protest Movements against the European Colonial Order (Chapel Hill: University of North Carolina Press, 1979).
}

8 \begin{tabular}{l|l} 
JOURNAL OF INDONESIAN ISLAM \\
VOLUME O2, NUMBER 01, JUNE 2008
\end{tabular} 
These cases are best understood as special case rather than evidence that Indonesian Muslims are given to violent jihad. Indeed, these are instances of specific uses of violence in support of the needs of the nation.

\section{Emergence of Radicalism}

The political repression of the Suharto Era, or the New Order regime, kept Islamism and radicalism at bay. The transition to democracy has opened the space for radical groups to emerge. ${ }^{17}$ The emergence of radical groups in the post-Suharto Era must be placed in context. Islam was not allowed to play a pre-eminent role in politics and policy making and the State was suspicious of Islam as a political force until near the end of the New Order. ${ }^{18}$ When Suharto allowed Islam to play a political role near the end of his regime, it was seen as an attempt to co-opt Islam to bolster his eroding legitimacy. Suharto "regularized" the political parties by reducing the number of political parties to 1 functional group and 2 "opposition" parties and required all mass-based organization to accept Pancasila as their sole philosophical basis. Therefore PPP, the party into which all the Islamic parties were folded, could not be proclaimed itself as Islamic. ${ }^{19}$ However, it used the ka'bah as its symbol and was seen as the Islamic party by many conservative Muslims. This also led NU and Muhammadiyah, the largest mass social organizations, whose combined membership tops more than 50 million mainstream Muslims ${ }^{20}$ to shift their focus to religious and social activities or as NU considered it a return to their roots. ${ }^{21}$

Radicalism is a by-product of the democratization of the political system. However for most Indonesian Muslims, radicalism is

\footnotetext{
17 Rizal Sukma, "Indonesia and the Challenge of Radical Islam after October 12," in Kumar Ramakrishna and See Seng Tan (eds.), After Bali: The Threat of Terrorism in Southeast Asia (Singapore: Institute of Defence and Strategic Studies, Nanyang Technological University, 2003), pp. 343, 350.

18 Ibid., p. 343.

${ }^{19}$ Ibid., p. 344.

20 Tatik S. Hafidz, "Assessing Indonesia's Vulnerability in the Wake of the AmericanLed Attack on Iraq," in Kumar Ramakrishna and See Seng Tan (eds.), After Bali: The Threat of Terrorism in Southeast Asia (Singapore: Institute of Defence and Strategic Studies, Nanyang Technological University, 2003), p. 386.

${ }^{21}$ Sukma, "Indonesia and the Challenge," p. 344.
} 
unacceptable if it uses violence or tries to limit freedom of thought and of having different opinions. Radical Islam is limited in its scope and outreach and is therefore a non-Issue outside of Java. Narrow interpretations of Islam, much less radical ones, are not well received by most Indonesians Muslims ${ }^{22}$

\section{Resistance to Radicalism}

There are number of reasons to belief that Indonesia will remain resilient to the challenge of radicalism. First, radical groups constitute only a tiny percentage of the Indonesian Muslim community. In 1999, pro-shari th parties only gained $14 \%$ of the votes -- PPP: $11 \%$; Partai Bulan Bintang: 2\%, and Partai Keadilan: 1\%. Second, NU and Muhammadiyah have continued their historical opposition to the establishment of shariath law ${ }^{23}$ Hasyim Muzadi flatly denies the possibility that anyone in the NU organization could be pro-shari sh (personal communication August 14, 2007). Third, most Indonesian Muslims embrace democracy. ${ }^{24}$ Fourth, there is a strong counterradical discourse, as seen in the group Liberal Islam Network (Jaringan Islam Liberal). Beyond this, the pesantren community is deeply committed to non-radicalism.

Given that university students fit best the demographic for recruitment into radical groups (18-25, strong western education, little Islamic education), several kyais have sought to inoculate this population either through pesantren created specifically for university students or by opening up their pesantren to university student. In either case, pesantren tradition is altered so that the students may daily leave the pesantren campus for outside education. The best example of this is Al-Hikam in Malang which was founded by Hasyim Muzadi who states that he had the specific purposes of creating anti-radicals. Elsewhere, ${ }^{25} \mathrm{I}$ detail the efforts of this pesantren and the ways in which they are defining a way in which to interact with the West, the modern world, and globalization in a specifically Islamic way. Pak Hasyim and other kyais assert that the kitab kuning (yellow books),

\footnotetext{
22 Ibid., pp. 349-350.

${ }^{23}$ Ibid., p. 348.

24 Ibid.

25 Ronald Lukens-Bull, "Two Sides of the Same Coin: Modernity and Tradition in Indonesian Islamic Education," Anthropology and Education Quarterly. 32(3): pp. 350-372.
} 
which include classical Sha $i>$ figh, are the best defense against radicalism. One cannot help but think that they are right. By staying within the traditional madhhab there is little room for radicalism; but by opening the gates of interpretation one is free to justify a wide range of activities.

\section{New Direction: Wide Survey}

During the Suharto era (1965-1998), it was reasonable to discuss the "pesantren community" in terms of central tendencies with some notable outliers. In that era, the central tendencies included religious pluralism, nationalism, and a decidedly non-Islamist agenda. In that context, the use of limited number of case studies supplemented by short visits to a larger but still limited number of cases was effective methodologically. In the post-Suharto era, two well-known radical groups, Laskar Jihad and Jama'ah Islamiyah, were based in pesantren. The media coverage has lead to the Princeton-based WordNet project to offer the definition of "a Muslim school in Indonesia operated by religious leaders; produces young militants skilled in jihad." This definition is reproduced in most major on-line dictionaries (e.g. dictionary.com, thefreedictionary.com, Rhymezone.com, lookwayup.com). In fact, there is no on-line dictionary that does not reproduce the WordNet definition in part or in whole. ${ }^{26}$ This definition fits in well with the media and policy understanding of similar schools called madrasab as "Universities of Jihad" as described in an influential Foreign Policy article. ${ }^{27}$

To date, research on pesantren has been limited to case studies. ${ }^{28}$ The larger studies are based on detailed case studies of a handful of institutions. Among institutions calling themselves "pesantren," there is considerable variation in curriculum as well as both student and faculty composition. Not only is it clear that some pesantrens are now involved in radicalism and even terrorism, it is clear that we can no longer talk about central tendencies nor use the case study approach. There is an almost desperate need to establish both the range and

\footnotetext{
26 The on-line encyclopedia, wikipedia, does not use this definition and draws on several academic sources. As well it should as I edited the entry.

${ }^{27}$ Husain Haqqani, "Islam's Medieval Outposts," Foreign Policy, November/December 2002.

28 Imron Arifin, Kepemimpinan Kyai: Kasus Pondok Pesantren Tebu Ireng (Malang: Kalimasada Press, 1993).
} 
distribution of variation in beliefs, practices, and knowledge that has emerged among pesantren scholars. To do this, the study of pesantren needs to engage mixed methodology. This would involve the use of qualitative research to understand the range of variation and the use of survey methods and quantitative analysis to map the distribution of that variation.

There are a number of areas in which changes may have taken place and need further investigation including demographics, curriculum, basic orientation, organization, and ritual activity. With the issue of demographics, the question is: has there been a change in the social-economic and educational backgrounds of students and their parents as well any shifts in political and religious affiliations? When considering curriculum, the question concerns whether there has been any significant shifts in the combinations of religious and secular subjects taught? Also of interest are any shifts in the religious

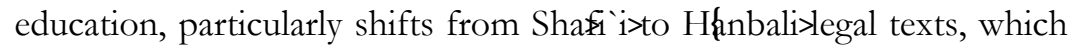
may indicate a shift toward a more Islamist understanding of the faith? Related to the question of curriculum is the question of orientation, that is how does the leadership see itself vis-à-vis both Islamist and advocates of Liberal Islam? The question of organization relates to both curriculum and orientation, in that some pesantren are mostly "family affairs," and so we might hypothesize a greater likelihood to shift both orientation and curriculum to either more Islamist of more liberal expressions. Finally, the question of devotional activities speak to the underlying religious dimensions of life in pesantren and understanding how ritual practice would relate to the other questions raised.

\section{New Direction: Educational Biographies}

Another direction worth exploring concerns sources of future of leadership for the Indonesian Islamic community. Pesantrens were once the premiere institution for the teaching and training of religious leaders and functionaries. In the 20th and early 21 st centuries, pesantren faced a number of challenges including the appeal of secular education as a way for students to seek a more financially promising future. Some pesantrens have met the demand for marketable skills and knowledge by adding government-recognized curriculum usually at the middle and high school levels. One result is that many of these pesantrens are no longer able to produce graduates who have the knowledge and skills to become religious leaders. The pesantren 
community has asked from whence will the future leadership come? One possible solution discussed in the mid-90s involved new forms of pesantren education. Another answer in the mid-90s was that Ph.D. holders would provide this needed leadership. In many regards this is the zenith of the path started in the 1970s with the establishment of the UIN/IAIN system.

The brightest and the best UIN/IAIN graduates often become faculty at their home institution. After several years of service, some may travel overseas to take advanced degrees. There are two basic paths at this point. The first is to receive a Fulbright or similar scholarship and study in the US or other Western countries. The other path involves study in the Middle East, usually Egypt. In either case, they return home to once again teach at their alma mater. It will be useful to explore the shifts in educational trajectories to explore whether there are any discernable patterns in the life and educational experiences that yield tolerant rather than intolerant points of view. Of particular interest will be the difference between those who complete their advanced studies in the West compared to those who do so in the Middle East. Within each of these categories, it will be necessary to examine other dimensions. For example, although many Muslim scholars who study in the United States as part of a scholarship program return home with a favorable view of the West in general, there are famous exceptions to this (i.e. Sayyid Qut\}). Also, what are the differences between those who study in Egypt (usually at AlAzhar) and those who are beginning to favor institutions in Saudi Arabia and Pakistan? Taken as an aggregate, these life histories should yield a sense of the kinds of shifts in education, thinking, and religious practice that Indonesia's increasing participation in global processes has required.

\section{Conclusion}

When the West seeks allies in its "War on Terror" it completely misreads the situation. In the first instance, it misreads the extent of the threat and associates terrorism with a much broader swatch of the Muslim community than is justified. One way in which it does this is to over generalize the role of traditional Islamic schools in radical Islam. It looks at certain madrasah in Pakistan and their tendency for involvement in violence and radicalism and generalizes to all similar schools including the Indonesian pesantren. When looking at Indonesia specifically, it looks at the few pesantren that have been 
associated with radical Islamism such as the home bases of both Laskar Jihad and the organization commonly referred to as Jama'ah Islamiyah, and then concludes that the pesantren community may be a threat source.

I have shown here that the argument that pesantrens are a source of radicalism is by and large misplaced. Pesantrens have a strong history of accommodation, pluralism, and non-Radicalism. Yes, pesantren have been mobilized to violence in the past, both in the War for Independence and in 1965-1966, but these can be understood as special cases. The pesantren tradition of accommodation, tolerance, and anti-radicalism is one that should be embraced and encouraged. It is the best hope for counteracting radicalism. []

\section{Bibliography}

Abdullah, Taufik. "The Pesantren in Historical Perspective." In Islam and Society in Southeast Asia, ed. Taufik Abdullah and Sharon Siddique. Singapore: Institute of Southeast Asian Studies, 1987.

Adas, Michael. Prophets of Rebellion: Millenarian Protest Movements against the European Colonial Order. Chapel Hill: University of North Carolina Press, 1979.

Arifin, Imron. Kepemimpinan Kyai: Kasus Pondok Pesantren Tebu Ireng. Malang: Kalimasada Press, 1993.

Boland, B.J. The Struggle of Islam in Modern Indonesia. The Hague: Nijhoff, 1971.

Dhofier, Zamakhsyari. The Pesantren Tradition: A Study of the Role of the Kyai in the Maintenance of the Traditional Ideology of Islam in Java. Doctoral Thesis submitted to The Australian National University, 1980.

- The Pesantren Tradition: A Study of the Role of the Kyai in the Maintenance of the Traditional Ideology of Islam in Java. Tempe: Program for Southeast Asian Studies, 1999.

Ghofir, Abdul et al. Sketsa Pondok Pesantren: Laporan Hasil Studi and Eksperimentasi Pondok Pesantren di Jawa Timur. Malang: Fakultas Tarbiyah IAIN Sunan Ampel, 1982.

Hafidz, Tatik S. "Assessing Indonesia's Vulnerability in the Wake of the American-Led Attack on Iraq." in Kumar Ramakrishna and 
See Seng Tan, eds. After Bali: The Threat of Terrorism in Southeast Asia. Singapore: Institute of Defence and Strategic Studies, Nanyang Technological University, 2003.

Haqqani, Husain. "Islam's Medieval Outposts” Foreign Policy November/December 2002.

Johns, Anthony. "Tariqah." In The Encyclopaedia of Religion. Mircea Eliade, editor in chief. New York: Macmillan Publishing Company, Vol. 14 (1987), pp. 342-352.

Kartodirdjo, Sartono. The Peasants' Revolt of Banten in 1888. The Hague: Martinus Nijhoff, 1966.

Lukens-Bull, Ronald. A Peaceful Jihad: Negotiating Identity and Modernity in Muslim Java. New York: Palgrave McMillian, 2005.

----.. "Two Sides of the Same Coin: Modernity and Tradition in Indonesian Islamic Education," Anthropology and Education Quarterly. 32(3): pp. 350-372.

Noer, Deliar. Administration of Islam in Indonesia. Ithaca: Cornell Modern Indonesia Project, 1978.

Pranowo, Bambang. "Traditional Islam in Contemporary Rural Java." In M.C. Ricklefs, ed. Islam in the Indonesian Social Context. Clayton: Monash University Center for Southeast Asian Studies Lecture Series, 1991.

Sukma, Rizal. "Indonesia and the Challenge of Radical Islam after October 12" in Kumar Ramakrishna and See Seng Tan, eds. After Bali: The Threat of Terrorism in Southeast Asia. Singapore: Institute of Defence and Strategic Studies, Nanyang Technological University, 2003.

Yunus, Mahmud. Sejarah Pendidikan Islam di Indonesia. Jakarta: Mutiara, 1979.

Woodward, Mark R. Islam in Java: Normative Piety and Mysticism in the Sultanate of Yogyakarta. Tucson: The University of Arizona Press, 1989. 